\title{
Peripheral blood monocytes and procalcitonin levels as predictors of $\beta 2$-microglobulin level in haemodialysis patients
}

\author{
Ioannis Koulouridis ${ }^{1}$, Efstathios Koulouridis ${ }^{2}$, Eleni Klonou ${ }^{3}$, Anastasios Fountoglou ${ }^{2}$ and Larisa Kouliasa ${ }^{2}$ \\ ${ }^{1}$ Department of Cardiology, St. Elizabeth's Medical Center, Boston, USA \\ ${ }^{2}$ Vacation Dialysis Center, Nephroxenia Corfu, Greece \\ ${ }^{3}$ Biochemical Laboratory, General Hospital of Corfu, Greece
}

\begin{abstract}
Background: $\beta 2$-microglubulin $(\beta 2-\mathrm{M})$ has been implicated in the pathogenesis of dialysis related amyloidosis (DRA). End-stage renal disease (ESRD) patients exhibit increased $\beta 2-\mathrm{M}$ levels. Therapeutic manipulations, in order to increase $\beta 2-\mathrm{M}$ elimination during dialysis, have not shown unequivocal benefit in lowering the incidence of DRA in ESRD patients. We believe that other factors, apart from haemodialysis session, may play a more important role in the pathogenesis of DRA.

Methods: We prospectively investigated 72 patients (46 men and 26 women), undergoing standard bicarbonate dialysis under a thrice weekly program, aged 65.8 \pm 13.6 (21-88) years, dialysis duration $68.3 \pm 64.1$ months. Ten patients (13.8 \%) exhibited carpal tunnel syndrome. Before haemodialysis session we estimated the following parameters: $\beta 2$-microglobulin, procalcitonin (PCT), C-reactive protein, intact-PTH, calcium, phosphate, calcium-phosphate product, magnesium, serum albumin and the absolute number of peripheral leucocytes (polymorphonuclear, lymphocytes, monocytes and eosinophils). We compared $\beta 2$-microglubulin and procalcitonin levels of our patients with the corresponding levels of 26 healthy controls, aged $32.1 \pm 12.2$ (18-64) years.
\end{abstract}

Results: Patients exhibited $\beta 2-\mathrm{M}$ levels 24 times higher than controls $(32.2 \pm 9.2 \mathrm{Vs} 1.35 \pm 0.29 \mathrm{mg} / \mathrm{L}, \mathrm{p}<0.0001)$ and PCT levels 8 times higher than controls $(0.82$ $\pm 0.72 \mathrm{Vs} 0.103 \pm 0.006 \mathrm{ng} / \mathrm{ml}, \mathrm{p}<0.0001)$. Statistical analysis showed a positive correlation between $\beta 2-\mathrm{M}$ levels and peripheral blood monocytes $(\mathrm{r}=0.303$, $\mathrm{p}=0.009)$ or $\beta 2-\mathrm{M}$ and procalcitonin levels $(\mathrm{r}=0.242, \mathrm{p}=0.04)$. Positive correlation was found also between $\beta 2-\mathrm{M}$ and peripheral monocytes among controls ( $\mathrm{n}=26, \mathrm{r}=0.478$, $\mathrm{p}=0.010)$. No association was found between $\beta 2-\mathrm{M}$ levels and membrane type, sterilization method or primary renal disease. Presence of carpal tunnel syndrome showed positive relationship with dialysis duration $(\mathrm{F}=8.6, \mathrm{p}=0.004)$ and serum calcium levels $(\mathrm{F}=4.24, \mathrm{p}=0.04)$.

Conclusions: ESRD patients showed considerably increased $\beta 2-\mathrm{M}$ and, in a lesser degree, procalcitonin levels compared to controls. $\beta 2-\mathrm{M}$ levels were associated with peripheral monocytes count and procalcitonin levels. Presence of carpal tunnel syndrome is associated with longer haemodialysis duration and higher serum calcium levels.

\section{Introduction}

After Assenat $\mathrm{H}$, et al. recognized amyloid deposition as the cause of carpal tunnel syndrome in haemodialysis patients, Gejyo F, et al. and Gorevic PD, et al. showed that the amyloid material was primarily composed of $\beta 2$ - microglobulin fibrils [1-3]. These and other observations led to the recognition of a new type of amyloidosis known as the dialysis related amyloidosis (DRA) which is not usually a systemic disease but involves mainly articular and periarticular tissues and subchondral bone leading to arthralgias, carpal tunnel syndrome (CTS) and destructive arthropathies [4]. In the early era of DRA its pathogenesis was directly related to the increased levels of $\beta 2-\mathrm{M}$ among dialysis patients and the dialysis modality by its shelf because of the activation of pro-inflammatory and inflammatory cytokines produced by the contact of blood with dialyzer membrane and the dialysis fluid. Following data showed that although $\beta 2-\mathrm{M}$ is constantly elevated among dialysis and pre-dialysis patients DRA becomes clinically evident after 5-10 years duration of dialysis treatment [4]. Moreover, although renal transplantation decreases effectively $\beta 2-\mathrm{M}$ levels pre-existing DRA does not regress [5]. Detailed investigation showed that amyloid material comprises and other constituents such as advanced glycation end products (AGEs) and the complex of b2-M/
AGEs is rather amyloidogenic than merely $\beta 2-\mathrm{M}[6,7]$. Interestingly Campistol JM, et al. showed a spontaneous formation of $\beta 2-\mathrm{M}$ fibrils in the supernatant cultures of peripheral mononuclear cells obtained from ESRD patients suffering from DRA [8]. The above data point to the possibility that DRA may be the result of more than one factor including the mediators of inflammation and certain peripheral blood lines participating in the innate immunity of the organism. In this study we attempt to seek the possible relationship between inter-dialysis $\beta 2-\mathrm{M}$ level and certain markers of inflammation such as CRP and PCT as well as certain cell lines of peripheral blood leucocytes. The effect of traditional predictors upon $\beta 2-\mathrm{M}$ level such as haemodialysis duration, dialyzers ultrafiltration, dialyzers membranes and mode of sterilization is also explored.

*Correspondence to: Efstathios Koulouridis, Vacation Dialysis Center, Nephroxenia Corfu, Greece, Tel: +306944276642; Fax: +302661022660; E-mail: koulef@otenet.gr

Key words: b2-microglobulin, peripheral blood monocytes, procalcitonin, carpal tunnel syndrome, calcium levels

Received: March 05, 2020; Accepted: March 13, 2020; Published: March 16, 2020 


\section{Subjects and methods}

\section{Study design}

In this prospective cohort study, we included 72 patients (46 men and 26 women). Informed consent was provided by all patients before their enrolment in the study. Included patients were under a thriceweekly, standard bicarbonate, hemodialysis schedule program for at least six months before enrolment in the study. Patients with active infection or a recent two-week febrile state were excluded from the study. Presence of carpal tunnel syndrome (CTS) was established by motor conduction velocity and sensory conduction velocity of the median nerve. Double reverse osmosis with intermediate storage tank was used to generate water for dialysate preparation. Twenty-six healthy individuals (14 males - 12 females), recruited from the hospital staff and blood donors were used as controls. The control group was not matched for age and gender with patients' group. After 48-hours inter-dialysis period and just before commencing dialysis session whole blood was aspirated from the arterial line and estimated the following parameters: $\beta 2$-microglobulin $(\beta 2-\mathrm{M})$, procalcitonin $(\mathrm{PCT}), \mathrm{C}$-reactive protein (CRP), intact-PTH (iPTH), calcium $(\mathrm{Ca})$, phosphate $(\mathrm{P})$, calciumphosphate product (CaXP), magnesium $(\mathrm{Mg})$, serum albumin (Alb) and the absolute number of peripheral leucocytes (polymorphonuclear, lymphocytes, monocytes and eosinophils). Detailed peripheral blood count, $\beta 2-\mathrm{M}$ and PCT were determined among controls. Serum $\beta 2-\mathrm{M}$ level $(\mathrm{mg} / \mathrm{L})$ and PCT $(\mathrm{ng} / \mathrm{ml})$ were estimated by chemiluminescence method, magnesium $(\mathrm{mg} / \mathrm{dl})$ by using the xylidyl blue method, serum phosphorous (mg/dl) by molybdate UV method, serum calcium (mg/ dl) by arsenazo III pigment method and albumin by bromocresol green. Intact iPTH $(\mathrm{pg} / \mathrm{ml})$ was estimated by immunoassay (sandwich method). All measurements were performed by AU 600/OLYMPUS equipment. Peripheral blood cells count was performed by flow cytometry.

\section{Statistical analysis}

Students T-test was used in order to compare $\beta 2-\mathrm{M}, \mathrm{PCT}$ and peripheral blood cells count between patients and controls. Multiple regression analysis was used in order to test the effect of prespecified variables (hemodialysis duration, PCT, CRP, iPTH, dialyzer ultrafiltration, Alb, $\mathrm{Ca}$ and monocytes) upon $\beta 2-\mathrm{M}$ level. One-way ANOVA was used to test the effect of binary variables upon $\beta 2-\mathrm{M}$ level and to test the association between CTS and individual variables (post-hoc multiple comparison test). All $\mathrm{p}$ values were two tailed and considered to be statistically significant at the 0,05 level.

\section{Results}

\section{Population characteristics}

Epidemiological data of study group are shown in Table 1. Mean Patients age was $65.8 \pm 13.6(21-88)$ years, hemodialysis duration 68.3 \pm 64.1 (6-282) months and hemodialysis time $202.8 \pm 33.3$ (135-270) minutes/session. Twelve patients (16.6\%) exhibited residual renal function. The cause of primary renal disease was: Glomerulonephritis (GN) in 25 (34.7\%). Diabetic nephropathy (DN) in $12(16.6 \%)$. Adult polycystic kidney disease (APKD) in $9(12.5 \%)$. Chronic pyelonephritis $(\mathrm{CPN})$ in $6(8.3 \%)$. Atheromatous renal disease (ARD) in $4(5.5 \%)$ and unknown origin (UKN) in $16(22.2 \%)$. Detailed characteristics of dialyzers used as well as number of patients per dialyzer are shown in Table 2.

Table 1. Epidemiological data of patients and controls

\begin{tabular}{|c|c|c|c|}
\hline & Patients $(n=72)$ & Controls $(n=26)$ & $\mathbf{p}$ \\
\hline Age (years) & $65.8 \pm 13.6(21-88)$ & $32.1 \pm 12.2(18-64)$ & $<0.001$ \\
\hline Gender $(\mathrm{M} / \mathrm{F})$ & $46 / 26$ & $14 / 12$ & $<0.050$ \\
\hline Haemodialysis duration (months) & $68.3 \pm 64.1(6-282)$ & - & - \\
\hline Haemodialysis time (minutes) & $202.8 \pm 33.3(135-270)$ & - & - \\
\hline Residual renal function $\left(\mathrm{ml} / \mathrm{min} / 1,72 \mathrm{~m}^{2}\right)$ & $3.6 \pm 2.1(0.7-7.3)$ & - & - \\
\hline Dialyzer ultrafiltration $(\mathrm{ml} / \mathrm{h} / \mathrm{mmHg})$ & $16.2 \pm 10.6(6.4-46)$ & - & - \\
\hline $\begin{array}{l}\text { Primary renal disease } \\
\text { Glomerulonephritis (GN) } \\
\text { Diabetic nephropathy (DN) } \\
\text { Adult polycystic kidney disease (APKD) } \\
\text { Chronic pyelonephritis (CPN) } \\
\text { Atheromatous renal disease (ARD) } \\
\text { Unknown origin (UKN) }\end{array}$ & $\begin{array}{c}25(34.7 \%) \\
12(16.6 \%) \\
9(12.5 \%) \\
6(8.3 \%) \\
4(5.5 \%) \\
16(22.2 \%) .\end{array}$ & $\begin{array}{l}- \\
- \\
- \\
- \\
- \\
-\end{array}$ & $\begin{array}{l}- \\
- \\
- \\
- \\
- \\
-\end{array}$ \\
\hline
\end{tabular}

Table 2. Detailed characteristics of dialyzers and patients' number per dialyzer

\begin{tabular}{|c|c|c|c|c|c|}
\hline Dialyzer type & Dialyzer membrane & Effective surface area $\left(\mathrm{m}^{2}\right)$ & $\begin{array}{c}\text { Ultrafiltration }(\mathrm{ml} / \mathrm{h} / \\
\mathrm{mmHg})\end{array}$ & Sterilization mode & No of pts. \\
\hline Rexeed 2.1 & Polysulphone & 2.1 & 16 & g-ray & 9 \\
\hline Rexeed 1.8 & Polysulphone & 1.8 & 13 & g-ray & 25 \\
\hline BLS-517G & Polysulphone & 1.68 & 17 & g-ray & 2 \\
\hline Helbio 180 & Polysulphone & 1.8 & 11 & g-ray & 1 \\
\hline Hemoflow F7 & Polysulphone & 1.6 & 6.4 & ETO & 8 \\
\hline Hemoflow F8 & Polysulphone & 1.7 & 7.5 & ETO & 2 \\
\hline FX-60 & Helixone & 1.4 & 33 & Steam & 1 \\
\hline FX-80 & Helixone & 1.8 & 46 & Steam & 8 \\
\hline EVAL & Vinyl alcohol & 1.6 & 10 & g-ray & 7 \\
\hline Polyflux 1.7 & Polyamide & 1.7 & 12.5 & Steam & 2 \\
\hline Polyflux 2.1 & Polyamide & 2.1 & 15 & Steam & 2 \\
\hline P-160 & Polyether Sulphone & 1.6 & 20 & g-ray & 1 \\
\hline P-180 & Polyether Sulphone & 1.8 & 22 & g-ray & 2 \\
\hline HP-180S & Polyether Sulphone & 1.8 & 13.7 & g-ray & 2 \\
\hline
\end{tabular}




\section{Comparison with the control group}

The results of estimated parameters are shown in Table 3. Patients exhibited about 24 times greater $\beta 2$-M level than controls $(32.2 \pm 9,2 \mathrm{Vs}$ $1.35 \pm 0.29, \mathrm{p}<0.0001)$ and about 8 times greater PCT level compared to controls $(0.82 \pm 0.72 \mathrm{Vs} 0.103 \pm 0.006, \mathrm{p}<0.0001)$. $\beta 2$-M level among 12 patients with residual renal function were $25.7 \pm 6.0(18-36.4 \mathrm{mg} / \mathrm{L})$. None of the patients, irrespective of residual renal function, exhibited normal $\beta 2$-M levels in contrast to PCT where a considerable proportion of patients $(35 / 72=48.6 \%)$ exhibited normal values. Patients exhibited significantly lower number of lymphocytes and greater number of monocytes and eosinophils (Table 3 ) in comparison to controls.

\section{Association of $\boldsymbol{\beta} 2-\mathrm{M}$ levels and PCT with predictors}

Multiple regression analysis (Table 4) showed that inter-dialysis $\beta 2-\mathrm{M}$ level was significantly related only to peripheral blood monocytes number (Figure 1, r=0.303, $\mathrm{p}=0.009)$ ) and PCT level $(\mathrm{r}=0.242, \mathrm{p}=0.040)$, whereas no relationship between $\beta 2-\mathrm{M}$ level and traditional factors such as dialysis duration and dialyzer ultra filtration was found. We also found a positive correlation between $\beta 2-\mathrm{M}$ level and peripheral blood monocytes count among controls ( $\mathrm{r}=0.478, \mathrm{p}=0.01$ ), (Table 4). We did not find any significant correlation between PCT and CRP levels $(\mathrm{n}=72$, $\mathrm{r}=0.038, \mathrm{p}=0.7$ ). By applying one-way ANOVA test we checked the possibility that categorical factors such as gender, dialyzer membrane type, dialyzer sterilization mode and primary renal disease may be affected $\beta 2$-M level, but no significant association was found (Table 5).

Table 3. Results of estimated parameters among patients and controls

\begin{tabular}{|c|c|c|c|}
\hline Parameter & Patients $(n=72)$ & Controls $(\mathrm{n}=26)$ & $\mathbf{p}$ \\
\hline $\begin{array}{l}\beta 2 \text {-microglobulin } \\
(\mathrm{mg} / \mathrm{L})\end{array}$ & $32.2 \pm 9.2(14.1-62.1)$ & $1.35 \pm 0.29(0.9-2.1)$ & $<0.001$ \\
\hline Procalcitonin (ng/ml) & $0.82 \pm 0.72(0.1-4.1)$ & $0.103 \pm 0.006(0.10-0.12)$ & $<0.001$ \\
\hline $\begin{array}{l}\text { Polymorphonuclear } \\
(\mathrm{c} / \mu \mathrm{l})\end{array}$ & $4313 \pm 1518(1510-8890)$ & $4122 \pm 1524(2060-8000)$ & 0.400 \\
\hline Lymphocytes (c/ $\mu \mathrm{l})$ & $1852 \pm 548(580-3380)$ & $2313 \pm 736(1460-4270)$ & 0.040 \\
\hline Monocytes $(\mathrm{c} / \mu \mathrm{l})$ & $726 \pm 208(340-1390)$ & $579 \pm 173(290-1150)$ & 0.004 \\
\hline Eosinophils (c/ $/ \mu \mathrm{l})$ & $312 \pm 191(10-1010)$ & $144 \pm 100(20-390)$ & $<0.001$ \\
\hline $\mathrm{CRP}(\mathrm{pg} / \mathrm{ml})$ & $0.89 \pm 1.21(0.12-6.32)$ & - & - \\
\hline iPTH (pg/ml) & $293.7 \pm 223(1-1125)$ & - & - \\
\hline Calcium (mg/dl) & $9.3 \pm 0.7(7.9-11.5)$ & - & - \\
\hline Phosphorus (mg/dl) & $4.8 \pm 1.3(1.7-8.6)$ & - & - \\
\hline $\mathrm{CaXP}$ & $45 \pm 13.9(15.6-76.6)$ & - & - \\
\hline Magnesium (mg/dl) & $2.6 \pm 0.6(1.7-6.3)$ & - & - \\
\hline Albumine (gr/dl) & $3.9 \pm 0.2(3.2-4.5)$ & - & - \\
\hline
\end{tabular}

Table 4. Multiple regression analysis between $\beta 2$-microglobulin and estimated variables. Two distinct analyses were performed among patients and controls

\begin{tabular}{|l|c|c|}
\hline Patients (n=72) & beta \\
\hline Predictor. & -0.186 & P \\
\hline $\begin{array}{l}\text { Haemodialysis duration } \\
\text { (months) }\end{array}$ & 0.242 & 0.130 \\
\hline PCT $(\mathrm{ng} / \mathrm{ml})$ & 0.103 & 0.040 \\
\hline CRP $(\mathrm{pg} / \mathrm{ml})$ & -0.093 & 0.380 \\
\hline iPTH $(\mathrm{pg} / \mathrm{ml})$ & -0.079 & 0.430 \\
\hline Dialyzer UF (ml/h/mmHg) & -0.106 & 0.510 \\
\hline Albumin $(\mathrm{gr} / \mathrm{dl})$ & -0.031 & 0.380 \\
\hline Calcium $(\mathrm{mg} / \mathrm{dl})$ & 0.303 & 0.790 \\
\hline Monocytes $(\mathrm{c} / \mu \mathrm{l})$ & & 0.009 \\
\hline Controls $(\mathbf{n}=\mathbf{2 6})$ & 0.270 & \\
\hline PCT-controls $(\mathrm{ng} / \mathrm{ml})$ & 0.478 & 0.120 \\
\hline Monocytes-controls $(\mathrm{c} / \mu \mathrm{l})$ & & 0.010 \\
\hline
\end{tabular}

Table 5. Analysis of variance between $\beta 2-\mathrm{M}$ and categorical variables in the patient group $(\mathrm{n}=72)$

\begin{tabular}{|c|c|c|}
\hline Variable & F & p \\
\hline Gender $(\mathrm{M} / \mathrm{F})$ & 2.32 & 0.100 \\
\hline Dialyzer membrane & 1.34 & 0.200 \\
\hline Sterilization & 1.91 & 0.100 \\
\hline Primary renal disease & 1.09 & 0.400 \\
\hline
\end{tabular}

\section{Association of carpal tunnel syndrome with predictors}

Ten out of 72 patients $(13,8 \%)$ exhibited CTS. We checked the effect of analysed parameters upon CTS appearance and we found that only haemodialysis duration $(\mathrm{F}=8.6, \mathrm{p}=0.004)$ and serum calcium level $(\mathrm{F}=4.24, \mathrm{p}=0.040)$ was significantly associated with CTS presence. Comparison of $\beta 2-\mathrm{M}$ levels between patients with and without CTS showed no statistically significant difference $(\mathrm{p}=0.400)$.

\section{Discussion}

$\beta 2$-microglobulin is the light chain of the major histocompatibility complex class-I antigens (HLA-I) and it is produced from every nucleated cell. Plasma level of protein is the result of dissociation from the heavy chain of the HLA-I complex and is known as "shedding" of the protein. $\beta 2-\mathrm{M}$ is almost exclusively excreted by the kidney and it is reabsorbed from proximal tubule cells which are capable to catabolize the protein leading to its clearance from the plasma. ESRD patients exhibit a considerable increase of $\beta 2-\mathrm{M}$ level compared to normal individuals. Hemodialysis patients exhibit higher level of $\beta 2-\mathrm{M}$ compared to chronic ambulatory peritoneal dialysis (CAPD). ESRD patients dialyzed with cuprophane membranes exhibited higher level of $\beta 2-\mathrm{M}$ compared to those dialyzed with polyacrylonitrile membranes [9]. Our data showed, as expected, that all patients exhibited abnormal levels of $\beta 2-\mathrm{M}$, even those with residual renal function (18-36.4 mg/L). A considerable variation between individual patients was observed (14.1-62.1 mg/L). It is known from previous studies that dialysis modality and dialyzer type influence $\beta 2-\mathrm{M}$ levels [10-12]. Considering that dialysis modality was similar for all our patients and nobody of them used bioincompatible dialyzers we could consider that factors other than dialysis modality influence primarily inter-dialysis levels of $\beta 2-\mathrm{M}$.

Procalcitonin is the precursor hormone of calcitonin, it is composed of 116 amino acids and possess a molecular weight of 13.000 Daltons. Under normal conditions it is produced by the C-cells of thyroid gland, the neuroendocrine cells of the lung and possibly the neuroendocrine cells of gastrointestinal tract as a result of hypercalcemia. Increased levels of the peptide are encountered in medullary thyroid cell carcinoma, in small cell lung carcinoma and in sepsis $[13,14]$. After the first publication of Assicot M, et al. showing that increased levels of PCT are encountered among patients with sepsis and inflammation numerous publications showed that PCT in sepsis is not originated from thyroid C-cells but almost from every tissue of the body such as fat, liver, lung, muscle, stomach, kidney, brain etc, [15]. Principal factors influencing extra-thyroid secretion of PCT are the bacterial lipopolysaccharide (LPS), the tumor necrosis factor- $\alpha$ (TNF $\alpha$ ) and interleukin-1 $\beta$ (Il-1 $\beta)$ [13].

A significant proportion of patients (51.3\%) exhibited PCT levels higher than $0.5 \mathrm{ng} / \mathrm{ml}$ which is defined as the upper normal value, according our laboratory. None of the patients exhibited sepsis or any form of active inflammation during observation period. This finding suggests, as previously reported by others [16], that PCT may be a marker of inflammation among dialysis patients. We did not find any 
significant correlation between PCT and CRP levels probably because we carefully excluded any patient with suspected inflammation during the previous two weeks period before enrolment in the study.

Our findings showed that $\beta 2-\mathrm{M}$ levels are primarily associated with peripheral monocytes count (Figure 1) and in a lesser degree with PCT levels. No relationship was found with traditional parameters such as dialysis duration, dialyzer ultrafiltration and dialyzer membrane type. According to our knowledge, a previous study found a similar relationship between $\beta 2-\mathrm{M}$ levels and PCT as well as CRP levels in dialysis patients [17]. The lack of any relationship between $\beta 2-\mathrm{M}$ levels and membrane type as well as dialyzer ultrafiltration may be explained by the fact that all patients used biocompatible membranes and any decrease of $\beta 2-\mathrm{M}$ levels during dialysis session was abolished during inter-dialysis period. These findings suggest that $\beta 2-\mathrm{M}$ levels in haemodialysis patients may be replenished during inter-dialysis period by new "shedding" from nucleated cells but with different amounts by each individual patient. The question is what determines the amount of $\beta 2-\mathrm{M}$ shedding during inter-dialysis period. Our study is not capable to answer this question.

Accumulated evidence suggests that peripheral monocytes play a crucial role in $\beta 2-\mathrm{M}$ production in haemodialysis patients either by producing cytokines, such as interleukin 1 (IL-1), tumor necrosis factor-alpha (TNFa), interleukin 6 (IL-6) and chemokines, such as monocyte chemoattractant protein-1 (MCP-1) which are capable to activate the monocyte/macrophage system participating in the immune and inflammatory response of the organism [18,19]. We found a strong association between peripheral monocytes and $\beta 2-\mathrm{M}$ levels which points towards the possibility that the main cell line responsible for $\beta 2-\mathrm{M}$ production, in ESRD patients, is the peripheral monocyte. Carreno MP, et al. [20], in their excellent work, showed that peripheral blood monocytes obtained from haemodialysis patients as well as from healthy controls were the principal cells which produced $\beta 2-\mathrm{M}$ after stimulation with LPS, IL-1, TNFa and C5 $\alpha$. Our finding that $\beta 2-\mathrm{M}$ levels were strongly related with peripheral blood monocytes not only among patients but also among controls suggests that peripheral blood monocytes might play a crucial role in $\beta 2-\mathrm{M}$ production. It is possible that the accumulation of $\beta 2-\mathrm{M}$ in the serum of haemodialysis patients is the combined result of diminished elimination of the protein via the diseased kidneys and increased shedding by peripheral monocytes as a

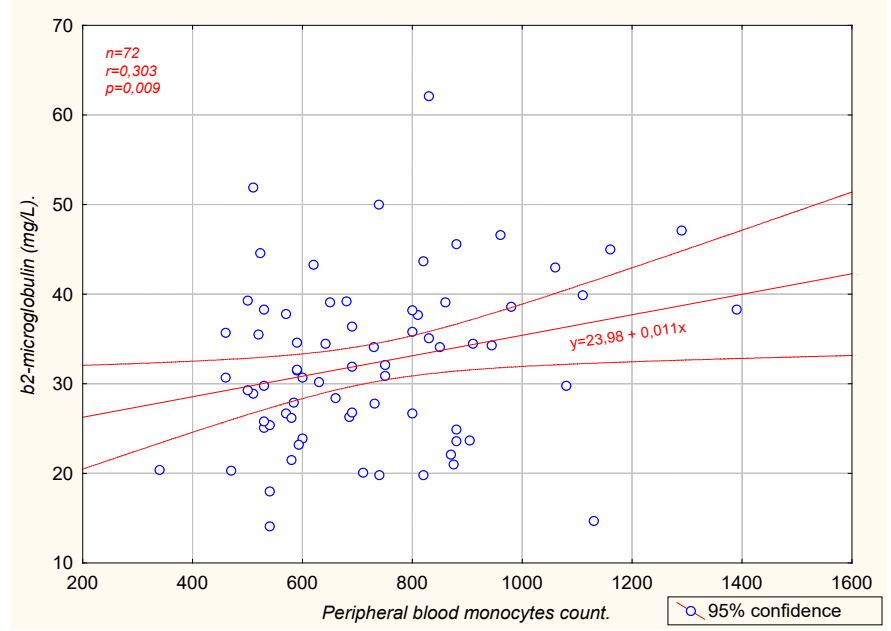

Figure 1. Peripheral blood monocytes emerged as the most important variable influencing $\beta 2$-microglobulin levels among dialysis patients result of stimulation by several inflammatory insults such as microbial toxins acquired by dialysis fluid, contact of the patient's blood by extracorporeal components, dialyzer membrane and other toxins not yet defined.

Correlation of $\beta 2-\mathrm{M}$ levels with PCT could be explained by the assumption that PCT might be an inflammatory marker in ESRD patients but the lack of any relationship between $\beta 2-\mathrm{M}$ or CRP levels, which represent a traditional inflammatory marker, render this assumption unconfirmed and points toward another possible explanation. HergetRosenthal S, et al. showed that PCT levels are gradually increased parallel to the decline of renal function among CKD patients (stage I-IV) as well as among patients receiving renal replacement therapy with the greater levels encountered among hemodialysis patients [21]. In the same work the authors showed that peripheral blood monocytes are capable to produce PCT and that the greater amount of PCT produced by peripheral blood monocytes obtained from haemodialysis patients as compared to controls or CKD or peritoneal dialysis patients. From the above mentioned data, it is obvious that peripheral blood monocytes of dialysis patients are capable to produce $\beta 2-\mathrm{M}$ and PCT and more importantly the two peptides share common stimulatory cytokines such as TNF- $\alpha$ and IL-1. These support an inference that the principal source of increased $\beta 2-\mathrm{M}$ and PCT levels in haemodialysis patients are the stimulated peripheral blood monocytes of these patients [13,20,22].

Appearance of CTS in haemodialysis patients has been considered previously as the main clinical expression of DRA [13,20,22]. Our findings of CTS being related to dialysis duration were expected but the association of CTS with calcium levels was not. Dialysis duration as well as age at the onset of haemodialysis have been previously shown to be the main predictors of DRA in dialysis patients [22]. According to our knowledge no previous studies have addressed the effect of serum calcium levels upon CTS appearance among these patients. Precipitation of calcium phosphate crystals in carpal tunnel with subsequent initiation of local micro-inflammation reaction might explain this finding but this hypothesis to be proven.

It seams likely that $\beta 2-\mathrm{M}$ among dialysis patients is determined by the immune system reaction upon unknown yet inflammatory factors, and CTS is the result of chronically elevated $\beta 2-\mathrm{M}$ levels and other precipitating factors one of them may be serum calcium level.

\section{Strengths and limitations}

Our study is among the first to address the question of a possible association of $\beta 2-\mathrm{M}$ with predictors other than dialysis modality. The use of a control group to compare our main outcome measurements provides additional internal validity to our analyses. We further minimized bias by using only bio-compatible dialyzers. The most difficult undertaking was the elimination of the effect of potential factors that confound the association of $\beta 2-\mathrm{M}$ or PCT levels and the various predictors. In our multivariable regression models, we forced factors that might play a confounding role according to current literature. Nevertheless, our patient group was not uniform; different causes of ESRD as well as varying prior exposure to dialysis modality might have influenced our results.

\section{Conclusion}

In our hypothesis generating analysis, factors additional to dialysis modality, such as peripheral monocytes count and in a lesser degree PCT levels, were associated with inter-dialysis levels of $\beta 2-\mathrm{M}$. 


\section{Statement}

Authors have not to declare any conflict of interest. The results presented in this paper have not been published previously in whole or part, except in abstract form.

\section{References}

1. Assenat H, Calemard E, Charra B, Laurent G, Terrat JC, et al. (1980) Hemodialysis : carpal tunnel syndrome and amyloid substance. Nouv Presse Med 9: 1715. [Crossref]

2. Gejyo F, Yamada T, Odani S, Nakagawa Y, Arakawa M et al. (1985) A new form of amyloid protein associated with haemodialysis was identified as b2-microglobulin. Biochem Biophys Res Comun 129: 701-706. [Crossref]

3. Gorevic PD, Casey TT, Stone WJ, DiRaimondo CR, Prelli FC, et al. (1985) Beta2 microglobulin is an amyloidogenic protein in man. $J$ Clin Invest 76: 2425-2429. [Crossref]

4. Bardin T, Zingraff J, Kuntz D, Drueke T (1986) Dialysis-Related Amyloidosis. Nephrol Dial Transplant 1: 151-154. [Crossref]

5. Mourad G, Argiles A (1996) Renal transplantation relieves the symptom but does not reverse beta 2-microglobulin amyloidosis. J Am Soc Nephrol 7: 798-804.

6. Drueke TB (2000) $\beta 2$-Microglobulin and amyloidosis. Nephrol Dial Transplant 15: 17-24. [Crossref]

7. Miyata T, Inagi R, Lida Y (1994) Involvement of b2-microglobulin modified with advanced glycation end products in the pathogenesis of hemodialysis-associated amyloidosis. J Clin Invest 93: 521-528.

8. Campistol JM, Sole M, Bombi JA (1992) In vitro spontaneous synthesis of b2microglobulin amyloid fibrils in peripheral blood mononuclear cell culture. Am J Pathol 141: 241-247.

9. Schardijn GH Statius van Eps LW (1987) $\beta 2$-microglobulin: its significance in the evaluation of renal function. Kidney Int 32: 635-641. [Crossref]

10. Hakim RM, Wingard RL, Husni L, Parker RA, Parker TF (1996) The effect of membrane biocompatibility on plasma $\beta 2$-microglobulin levels in chronic haemodialysis patients. J Am Soc Nephrol 7: 472-478.
11. Jahn B, Betz M, Deppisch R, Jansen O, Hansch GM, et al. (1991) Stimulation of beta2-microglobulin synthesis in lymphocytes after exposure to Cuprophane dialyzer membranes. Kidney Int 40: 285-290.

12. Zaoui PM, Stone WJ, Hakim RM (1990) Effects of dialysis membrane on beta2microglobulin production and cellular expression. Kidney Int 38: 962-968. [Crossref]

13. Becker KL, Snider R, Nylen ES (2010) Procalcitonin in sepsis and systemic inflammation: a harmful biomarker and a therapeutic target. Br J Pharmacol 159: 253263. [Crossref]

14. Maruna P, Nedelnikova, Gurlich R (2000) Physiology and genetics of procalcitonin. Physiol Res 49: S57-S61. [Crossref]

15. Assicot M, Gendrel D, Carsin H, Raymond J, Guilbaud J, et al. (1993) High serum procalcitonin concentrations in patients with sepsis and infection. Lancet 341: 515-518. [Crossref]

16. Level C, Chauveau P, Delmas Y, Lasseur C, Pellé G, et al. (2001) Procalcitonin: a new marker of inflammation in haemodialysis patients? Nephrol Dial Transplant 16: 980-986. [Crossref]

17. Kalocheretis P, Revela I, Spanou E, Drouzas A, Makriniotou I, et al. (2008) Strong correlation of B2-Microglobulin (B2-m) with procalcitonin (PCT) in the serum of chronic haemodialysis patients: a role for infections in the dialysis-related amyloidosis? Renal Failure 30: 1-5. [Crossref]

18. Akahoshi T, Kobayashi N, Hosaka S, Sekiyama N, Wada C, et al. (1995) In-vivo induction of monocytes chemotactic and activating factor in patients with chronic renal failure. Nephrol Dial Transplant 10: 2244-2249. [Crossref]

19. Pertosa G, Marfella C, Tarantino EA et al. (1991) Involvement of peripheral blood monocytes in haemodialysis: in vivo induction of tumour necrosis factor alpha, interleukin 6 and beta2-microglobulin. Nephrol Dial Transplant 6: 18-23.

20. Carreno MP, Rousseau Y, Poignet JL (1997) Dissociation between $\beta 2$-microglobulin production and IL-1 production in haemodialysis patients. Nephrol Dial Transpl 12: 2365-2374

21. Herget-Rosenthal S, Klein T, Marggraf G, Hirsch T, Jakob HG, et al. (2005) Modulation and source of procalcitonin in reduced renal replacement therapy. Scand J Immunol 61: 180-186. [Crossref]

22. Miyata T, Jadoul M, Kurokawa K, Van Ypersele De Strihou C (1998) B-2 microglobulin in renal disease. J Am Soc Nephrol 9: 1723-1735. [Crossref]

Copyright: (C2020 Koulouridis I. This is an open-access article distributed under the terms of the Creative Commons Attribution License, which permits unrestricted use, distribution, and reproduction in any medium, provided the original author and source are credited. 